\title{
PENILAIAN RASIONALITAS PENGOBATAN DIARE PADA BALITA DI PUSKESMAS BOGOR UTARA TAHUN 2016
}

\author{
Lusi Indriani $^{1}$, Devi Fitriyanti ${ }^{2}$, Amalul Ahli Azzikri ${ }^{3}$ \\ ${ }^{1,3}$ Program Studi Farmasi, Fakultas Matematika dan Ilmu Pengetahuan Alam \\ Universitas Pakuan Bogor \\ ${ }^{2}$ Puskesmas Bogor Utara Kota Bogor \\ Email: lusi.apoteker@gmail.com
}

\begin{abstract}
ABSTRAK
Penyakit diare masih menjadi masalah kesehatan masyarakat di negara-negara berkembang. Menurut WHO, diare mengakibatkan 2,5 juta kematian setiap tahun dimana $80 \%$ korban adalah balita. Penyakit ini sering menimbulkan Kejadian Luar Biasa (KLB) dengan kematian tinggi terutama di Indonesia Timur. Riskesdas tahun 2007 melaporkan bahwa diare masih merupakan penyebab kematian utama pada bayi usia 29 hari - 11 bulan $(31,4 \%)$ dan anak balita usia 12 - 59 bulan $(25,2 \%)$. Laporan Riskesdas 2013 menyatakan bahwa period prevalence diare di Indonesia adalah 7\%, dan pada balita $12,2 \%$. Penelitian ini bertujuan untuk menilai rasionalitas pengobatan diare pada balita di Puskesmas Bogor Utara Kota Bogor tahun 2016 berdasarkan kriteria tepat indikasi, tepat pemilihan obat, tepat dosis, tepat cara pemberian obat dan tepat lama pengobatan. Hasil penelitian menunjukkan bahwa penilaian rasionalitas pengobatan diare pada balita di Puskesmas Bogor Utara Kota Bogor tahun 2016 antara lain berdasarkan tepat indikasi adalah $100 \%$, tepat pemilihan obat 97,93\%, tepat dosis $91,73 \%$, tepat cara pemberian $100 \%$, dan tepat lama pengobatan $93,02 \%$.
\end{abstract}

Kata kunci: Diare, balita, rasionalitas pengobatan, Puskesmas Bogor Utara

\section{RATIONALITY ASSESSMENT IN DIARRHEA TREATMENT OF TODDLERS AT NORTH BOGOR PUBLIC HEALTH CENTER 2016}

\begin{abstract}
Diarrhea is still a public health problem in developing countries. According to WHO, diarrhea results in 2.5 million deaths each year where $80 \%$ of the victims are toddlers. This disease often leads to Extraordinary Events (KLB) with high mortality, especially in Eastern Indonesia. Riskesdas in 2007 reported that diarrhea was still the main cause of death in infants aged 29 days - 11 months (31.4\%) and children under the age of 12 - 59 months (25.2\%). The 2013 Riskesdas report states that the period prevalence of diarrhea in Indonesia is $7 \%$, and for toddlers $12.2 \%$. This study aimed to assess the rationality of the treatment of diarrhea in toddlers at North Bogor Public Health Center in 2016 based on precise criteria of indication, precise selection of drugs, appropriate dose, appropriate way of administration and appropriate duration of treatment. The results showed that the assessment of rationality of the treatment of diarrhea in toddlers at North Bogor Public Health Center in 2016, among others, based on precise indication of $100 \%$, the precise selection of drugs was $97.93 \%$, appropriate dose was $91.73 \%$, appropriate way of administration was $100 \%$, and appropriate duration of treatment was $93.02 \%$.

Keywords: Diarrhea, toddlers, rationality of treatment, North Bogor Public Health Center
\end{abstract}




\section{PENDAHULUAN}

Penyakit diare masih merupakan masalah kesehatan masyarakat di negaranegara berkembang. Menurut WHO, diare mengakibatkan 2,5 juta kematian setiap tahun dengan $80 \%$ korban di antaranya adalah balita. Penyakit ini sering menimbulkan Kejadian Luar Biasa (KLB) dengan kematian tinggi terutama di Indonesia Timur. Riskesdas tahun 2007 melaporkan bahwa diare masih merupakan penyebab kematian utama pada bayi usia 29 hari - 11 bulan $(31,4 \%)$ dan anak balita usia 12 - 59 bulan $(25,2 \%)$. Sedangkan, laporan Riskesdas 2013 menyatakan period prevalence diare di Indonesia adalah 7\%, dan pada balita 12,2\% (Kemenkes RI, 2013).

Pada tahun 2000 IR (Incident Rate) penyakit diare di Indonesia tahun 2010 naik menjadi 411/1000 penduduk. KLB diare juga masih sering terjadi, dengan CFR (Case Fatality Rate) yang masih tinggi (Kemenkes RI, 2011). Penyakit diare masuk ke dalam urutan ke 6 dari 10 penyakit utama yang terdata di instalasi rawat jalan Puskesmas Kota Bogor tahun 2015 dengan jumlah kasus sebanyak 12116 kasus atau sekitar 4,26 \% (Dinas Kesehatan Kota Bogor, 2015).

Data kasus diare per kecamatan di Kota Bogor menunjukkan bahwa kasus tertinggi diare untuk tahun 2015 berada di wilayah kerja Kecamatan Bogor Utara yang membawahi 8 wilayah kelurahan yaitu sebanyak 5330 jumlah kasus. Diantara kasus diare yang ditangani pada wilayah kecamatan Bogor Utara adalah sebanyak 1325 kasus (Dinas Kesehatan Kota Bogor, 2016).

\section{METODOLOGI PENELITIAN Rancangan Penelitian}

Penelitian ini adalah penelitian observasional yang bersifat deskriptif dengan pendekatan retrospektif, yaitu penelitian yang berusaha melihat kebelakang (Backward looking).

\section{Waktu dan Tempat Penelitian}

Lokasi dalam penelitian ini dilakukan di Puskesmas Bogor Utara Kota Bogor pada Bulan Juni sampai Agustus tahun 2017.

\section{Populasi dan Sampel}

Populasi yang digunakan dalam penelitian ini adalah seluruh pasien balita yang berobat di Puskesmas Bogor Utara Kota Bogor dan didiagnosis menderita penyakit diare.

Sampel penelitian ini adalah seluruh pasien balita yang berobat di Puskesmas Bogor Utara Kota Bogor dan didiagnosis menderita penyakit diare yang memenuhi kriteria inklusi sampel.

\section{Kriteria Inklusi dan Eksklusi}

Kriteria inklusi dalam penelitian ini adalah pasien balita yang didiagnosis menderita penyakit diare non infeksius yang mendapatkan pengobatan di Puskesmas Bogor Utara Kota Bogor periode Januari-Desember tahun 2016. Kriteria eksklusi penelitian ini adalah data resep atau rekam medis yang tidak lengkap untuk menilai pengobatan diare pada balita.

\section{Teknik Pengumpulan Data}

Data dikumpulkan dengan cara melihat data resep dan data rekam medis pasien balita yang didiagnosa diare kemudian data disesuaikan dengan pola pengobatan yang rasional sesuai dengan modul penggunaan obat rasional (Kemenkes RI, 2011a) dan panduan sosialisasi tatalaksana diare balita (kemenkes RI, 2011b). Prinsip tatalaksana diare pada balita adalah Lima Langkah Tuntaskan Diare (LINTAS DIARE) yang didukung oleh Ikatan Dokter Anak Indonesia dengan rekomendasi WHO (Kemenkes RI, 2011b). 


\section{Analisis Data}

Analisis data yang dilakukan menggunakan analisis data univariat untuk mendapatkan gambaran distribusi dalam bentuk tabel distribusi frekuensi dengan jumlah dan ukuran persentase masingmasing kelompok. Data yang dianalisa antara lain distribusi ketepatan indikasi obat, ketepatan pemilihan obat, ketepatan dosis, ketepatan cara pemberian obat dan ketepatan lama pemberian obat.

\section{HASIL DAN PEMBAHASAN Karakteristik Pasien}

Hasil penelitan menunjukkan bahwa karakteristik pasien balita yang menderita diare dan berobat di Puskesmas Bogor Utara tahun 2016 berdasarkan jenis kelamin dan umur dapat dilihat pada Tabel 1.

Tabel 1. Karakteristik Pasien berdasarkan Jenis Kelamin dan Umur ( $\mathrm{N}=153)$

\begin{tabular}{|c|c|c|c|}
\hline No. & $\begin{array}{c}\text { Karakteristik } \\
\text { Pasien }\end{array}$ & Jumlah & $\begin{array}{c}\text { Persentase } \\
(\%)\end{array}$ \\
\hline & Jenis kelamin & & \\
\hline 1 & Laki-laki & 80 & 52,30 \\
\hline \multirow[t]{2}{*}{2} & Perempuan & 73 & 47,70 \\
\hline & Total & 153 & 100 \\
\hline & Umur & & \\
\hline 1 & $0-12$ bulan & 57 & 37,30 \\
\hline \multirow[t]{2}{*}{2} & $13-59$ bulan & 96 & 62,70 \\
\hline & Total & 153 & 100 \\
\hline
\end{tabular}

Dari tabel diatas diperoleh bahwa pasien balita dengan jenis kelamin lakilaki lebih banyak yaitu 80 orang balita $(52,30 \%)$, sedangkan jenis kelamin perempuan adalah sebanyak 73 orang $(47,70 \%)$. Perbedaan jenis kelamin tidak menjadi faktor penyebab timbulnya diare karena anak laki-laki dan perempuan sama-sama mempunyai risiko terserang diare terkait kebersihan diri, lingkungan, dan sanitasi (Mulyani, 2006).

Karakteristik pasien berdasarkan umur menunjukkan bahwa pasien diare paling banyak adalah dengan rentang umur 13-59 bulan yaitu sebanyak 96 orang $(62,70 \%)$. Hal ini dikarenakan kelompok usia 13-59 bulan adalah kelompok anak yang mulai aktif bermain dan rentan terkena infeksi penyakit terutama diare. Anak pada kelompok umur ini dapat terkena infeksi bakteri penyebab diare pada saat bermain di lingkungan yang kotor serta melalui cara hidup yang kurang bersih (Wulandari, 2012), dan masalah kebersihan makanan termasuk kebersihan botol susu (Hikmawati, 2012). Hal ini juga dipengaruhi oleh faktor imunodefisiensi masing-masing yaitu apabila daya tahan tubuh balita baik maka tubuh dapat menahan patogen/kuman yang masuk kedalam tubuh, sedangkan apabila daya tahan tubuh balita menurun maka tubuh tidak dapat menahan patogen/kuman yang masuk kedalam tubuh (Sukardi, 2016). Selain itu secara fisiologis sistem pencernaan balita yang belum cukup matur (organ-organnya belum matang), sehingga rentan terkena penyakit saluran pencernaan (Markum, 1998).

\section{Rasionalitas Pengobatan Tepat Indikasi}

Hasil penilaian rasionalitas pengobatan diare pada balita di Puskesmas Bogor Utara tahun 2016 yang diperoleh dari 387 resep obat berdasarkan kriteria tepat indikasi adalah seperti yang tertera pada Tabel 2 . 
Tabel 2. Rasionalitas berdasarkan Ketepatan Indikasi (N=387)

\begin{tabular}{lccccc}
\hline Jenis Obat & Indikasi & Jumlah & $\begin{array}{c}\text { Persentase } \\
(\%)\end{array}$ & Tepat & $\begin{array}{c}\text { Tidak } \\
\text { Tepat }\end{array}$ \\
\hline Oralit & Diare & 145 & 37,47 & $\sqrt{ }$ & \\
Zinc & Diare & 150 & 38,76 & $\sqrt{ }$ & \\
Parasetamol syr & Demam & 73 & 18,86 & $\sqrt{ }$ & \\
Antasid syr & Kembung & 8 & 2,07 & $\sqrt{ }$ & \\
Vitamin & Imunitas & 10 & 2,58 & $\sqrt{ }$ & \\
Domperidon & Mual & 1 & 0,26 & $\sqrt{ }$ & \\
\hline Jumlah & & 387 & $100 \%$ & $100 \%$ & 0 \\
\hline
\end{tabular}

Penggunaan Obat Rasional (POR) menjelaskan bahwa ketepatan indikasi obat didefinisikan sebagai kegunaan suatu obat pada kondisi penyakit tertentu (Kemenkes RI, 2011a). Terapi diare yang diberikan pada balita umumnya adalah oralit dan zink. Sedangkan terapi tambahan untuk keluhan nyeri, mual, maupun gangguan lainnya antara lain parasetamol sirup, antasid sirup, domperidon, vitamin $\mathrm{C}, \mathrm{B} 6$ atau $\mathrm{B}$ kompleks. Penelitian ini difokuskan pada diare non infeksius sehingga tidak memerlukan terapi antibiotik. Dapat disimpulkan bahwa rasionalitas pengobatan diare pada balita berdasarkan kategori tepat indikasi adalah $100 \%$. Hal ini sesuai dengan tatalaksana penderita diare yang standar di

sarana kesehatan melalui Lima Langkah Tuntaskan Diare (LINTAS DIARE) bahwa pengobatan diare pada balita terdiri dari oralit, zink, makan (ASI atau ASI+MP ASI), antibiotik selektif, dan nasihat (Kemenkes RI, 2011b).

\section{Tepat Pemilihan Obat}

Hasil penilaian rasionalitas pengobatan diare pada balita di Puskesmas Bogor Utara tahun 2016 berdasarkan kriteria tepat pemilihan obat sesuai pada Tabel 3.

Tabel 3. Rasionalitas berdasarkan Ketepatan Pemilihan Obat $(\mathrm{N}=387)$

\begin{tabular}{lcccc}
\hline \multicolumn{1}{c}{ Jenis Obat } & Jumlah & Persentase $(\%)$ & Tepat & Tidak Tepat \\
\hline Oralit & 3 & 0,77 & $\sqrt{ }$ & \\
Oralit + zinc & 284 & 73,39 & $\sqrt{ }$ & \\
Zinc & 8 & 2,07 & & $\sqrt{ }$ \\
Parasetamol syr & 73 & 18,86 & $\sqrt{ }$ & \\
Antasid syr & 8 & 2.07 & $\sqrt{ }$ & \\
Vitamin & 10 & 2,58 & $\sqrt{ }$ & \\
Domperidon & 1 & 0,26 & $\sqrt{ }$ & \\
\hline Jumlah & 387 & 100 & $97,93 \%$ & $2,07 \%$ \\
\hline
\end{tabular}

Dilihat dari tabel di atas dapat disimpulkan bahwa rasionalitas pengobatan diare pada balita berdasarkan pemilihan obat yang tepat atau sesuai diperoleh sebanyak 379 resep $(97,93 \%)$, sedangkan yang tidak tepat diperoleh sebanyak 8 resep $(2,07 \%)$. Pada kasus diare balita, terapi yang dianjurkan sesuai tatalaksana diare yaitu pemberian cairan oralit dan tablet zinc.
Prinsip pengobatan oralit didasarkan bahwa absorbsi natrium dalam usus difasilitasi oleh bahan organik seperti glukosa dan asam amino. Bila cairan isotonik yang diberikan mengandung glukosa dan garam natrium dengan kadar seimbang, maka akan terjadi absorbsi natrium dan glukosa. Hal inilah yang menyebabkan suatu larutan dengan osmolaritas rendah seperti yang dimiliki 
Oralit tetap mempertahankan rasio natrium dan glukosa. Kandungan kalium dalam Oralit ditujukan untuk mengganti kalium yang hilang selama diare. Sitrat hidrat berfungsi sebagai korektor basa untuk mengatasi keadaan asidosis yang terjadi akibat diare dan dehidrasi (Made, 2012). Zinc merupakan nutrisi esensial yang penting bagi pertumbuhan balita. Pemberian zinc selama 10 hari terbukti dapat memperbaiki mukosa usus yang rusak dan membantu sistem kekebalan tubuh.

Hasil penelitian menunjukkan angka yang tidak tepat dalam pemilihan obat yaitu sebesar 2,07 \%. Pemberian obat pada resep terdapat pemberian tablet zinc saja atau cairan oralit saja. Berdasarkan pedoman tatalaksana diare pada balita pemberian oralit saja dirasakan sudah tepat dalam pengobatan diare balita untuk menghindari terjadinya dehidrasi. Tetapi sebagian pasien hanya diberikan terapi zinc saja sehingga pemberian dianggap belum tepat karena untuk pasien diare non dehidrasi tetap harus ditambahkan oralit untuk mencegah dehidrasi (Kemenkes RI, 2011b). Pemberian yang tidak sesuai ini dikhawatirkan akan mengurangi efektivitas terapi yang diinginkan dan juga memperbesar resiko terjadinya dehidrasi pada balita. Dehidrasi pada balita memiliki resiko dan potensi terjadinya kematian.

\section{Tepat Dosis}

Hasil penilaian rasionalitas pengobatan diare pada balita di Puskesmas Bogor Utara tahun 2016 berdasarkan kriteria tepat dosis yaitu seperti yang tertera pada Tabel 4.

Tabel 4. Rasionalitas berdasarkan Ketepatan Dosis $(\mathrm{N}=387)$

\begin{tabular}{|c|c|c|c|c|c|}
\hline & Dosis Obat & Jumlah & $\begin{array}{c}\text { Persentase } \\
(\%)\end{array}$ & Tepat & $\begin{array}{l}\text { Tidak } \\
\text { Tepat }\end{array}$ \\
\hline \multicolumn{6}{|l|}{ Oralit } \\
\hline- & setelah BAB & 35 & 9,04 & $\sqrt{ }$ & \multirow{14}{*}{$\begin{array}{l}\sqrt{ } \\
\sqrt{ }\end{array}$} \\
\hline- & ad lib & 49 & 12,66 & $\sqrt{ }$ & \\
\hline- & p.r.n & 16 & 4,13 & $\sqrt{ }$ & \\
\hline- & (1-3)x1 bungkus & 23 & 5,94 & $\sqrt{ }$ & \\
\hline- & Tanpa informasi & 22 & 5,69 & & \\
\hline \multicolumn{5}{|l|}{ Zinc } & \\
\hline- & $1 \mathrm{x}^{1 / 2}$ usia $<6$ bulan & 12 & 3,10 & $\sqrt{ }$ & \\
\hline- & $1 \mathrm{x} 1$ usia $<6$ bulan & 3 & 0,78 & & \\
\hline- & $1 \mathrm{x}^{1 / 2}$ usia $\geq 6$ bulan & 7 & 1,81 & & \\
\hline- & $1 \times 1$ usia $\geq 6$ bulan & 128 & 33,07 & $\sqrt{ }$ & \\
\hline \multicolumn{2}{|c|}{ Parasetamol syr 3x(1/2-1) } & 73 & 18,86 & $\sqrt{ }$ & \\
\hline \multicolumn{2}{|c|}{ Antasid syr $3 x(1 / 2-1)$} & 8 & 2,07 & $\sqrt{ }$ & \\
\hline \multicolumn{2}{|c|}{ Vitamin $1 x 1$} & 10 & 2,58 & $\sqrt{ }$ & \\
\hline \multicolumn{2}{|c|}{ Domperidon 2x1 } & 1 & 0,26 & $\sqrt{ }$ & \\
\hline \multicolumn{2}{|l|}{ Total } & 387 & 100 & 91,73 & 8,27 \\
\hline
\end{tabular}

Rasionalitas pengobatan diare pada balita berdasarkan dosis yang tepat atau sesuai diperoleh sebanyak 355 resep $(91,73 \%)$, sedangkan yang tidak tepat diperoleh sebanyak 32 resep $(8,27 \%)$. Hasil persentase tersebut menunjukkan ketepatan dosis pengobatan pada balita sudah menunjukkan hasil yang baik, namun masih ada peresepan obat yang tidak sesuai yaitu sebesar $8,27 \%$. Dosis oralit yang dianjurkan adalah diberikan setiap mencret atau diare agar terhindar dari terjadinya dehidrasi. Dalam resep oralit sebagian tidak terdapat informasi 
dosis penggunaannya, namun hanya dituliskan nama obat (oralit). Hal ini dapat mengurangi efektivitas terapi. Dosis zinc yang dianjurkan adalah diberikan sekali sehari selama 10 hari berturut-turut sebanyak 1 tablet untuk balita di atas usia 6 bulan dan $1 / 2$ tablet untuk balita di bawah usia 6 bulan. Pemberian dosis obat yang berlebih dengan rentang terapi yang sempit beresiko timbulnya efek samping sedangkan pemberian dosis yang kurang tidak akan menjamin tercapainya efek terapi yang diharapkan (Kemenkes, 2011b).

\section{Tepat Cara Pemberian}

Hasil penilaian rasionalitas pengobatan diare pada balita di Puskesmas Bogor Utara tahun 2016 berdasarkan criteria tepat cara pemberian obat adalah seperti yang tertera pada Tabel 5.

Tabel 5. Rasionalitas berdasarkan Ketepatan Cara Pemberian Obat (N=387)

\begin{tabular}{lccccc}
\hline \multicolumn{1}{c}{ Jenis Obat } & Cara Pemberian & Jumlah & $\begin{array}{c}\text { Persentase } \\
(\%)\end{array}$ & Tepat & Tidak Tepat \\
\hline Oralit & Larutan oral & 145 & 37,47 & $\sqrt{ }$ & \\
Zinc & Larutan oral & 150 & 38,76 & $\sqrt{ }$ & \\
Parasetamol syr & Oral & 73 & 18,86 & $\sqrt{ }$ & \\
Antasid syr & Oral & 8 & 2,07 & $\sqrt{ }$ & \\
Vitamin & Oral & 10 & 2,58 & $\sqrt{ }$ & \\
Domperidon & Oral & 1 & 0,26 & $\sqrt{ }$ & \\
\hline Jumlah & & 387 & $100 \%$ & $100 \%$ & 0 \\
\hline
\end{tabular}

Rasionalitas pengobatan diare pada balita berdasarkan cara pemberian diperoleh hasil yang tepat sebesar $100 \%$ atau seluruh resep memenuhi kriteria rasionalitas pengobatan. Berdasarkan pedoman tatalaksana pengobatan diare pada balita, pengobatan oralit dilakukan dengan cara melarutkan 1 sachet serbuk oralit dengan $200 \mathrm{cc}$ air matang atau air teh lalu diberikan kepada balita yang mengalami diare secara perlahan-lahan atau sedikit-sedikit hingga habis atau balita tidak kelihatan haus, sedangkan penggunaan tablet zinc dengan cara melarutkan tablet zinc dalam 1 sendok air matang atau ASI lalu diberikan pada balita dengan segera. Bila masih terdapat potongan kecil tablet, maka dilarutkan kembali beberapa kali hingga 1 dosis penuh. Pedoman pemberian oralit dan zinc ini telah dilakukan melalui pemberian informasi obat (PIO) oleh dokter maupun petugas kefarmasian di puskesmas sehingga kerasionalan pemberian zinc dan oralit diperoleh hasil yang tepat (Kemenkes, 2011b).

\section{Tepat Lama Pengobatan}

Hasil penilaian rasionalitas pengobatan diare pada balita di Puskesmas Bogor Utara tahun 2016 berdasarkan kriteria tepat lama pengobatan adalah seperti pada Tabel 6 .

Tabel 6. Rasionalitas berdasarkan Ketepatan Lama Pengobatan (N=387)

\begin{tabular}{lccccc}
\hline \multicolumn{1}{c}{ Jenis Obat } & Lama Pengobatan & Jumlah & Persentase (\%) & Tepat & Tidak Tepat \\
\hline Oralit & Sampai berhenti & 145 & 37,47 & $\sqrt{ }$ & \\
Zinc & 10 hari & 123 & 38,76 & $\sqrt{ }$ & $\sqrt{ }$ \\
& $<10$ hari & 27 & & & \\
Parasetamol syr & 1 hari & 73 & 18,86 & $\sqrt{ }$ & \\
Antasid syr & $1-3$ hari & 8 & 2,07 & $\sqrt{ }$ & \\
Vitamin & $1-3$ hari & 10 & 2,58 & $\sqrt{ }$ & \\
Domperidon & $1-3$ hari & 1 & 0,26 & $\sqrt{ }$ & \\
\hline Jumlah & & 387 & $100 \%$ & $93,02 \%$ & 6,98 \\
\hline
\end{tabular}


Rasionalitas pengobatan diare pada balita berdasarkan lama pengobatan yang tepat atau sesuai diperoleh sebanyak 360 resep $(93,02 \%)$, sedangkan yang tidak tepat diperoleh sebanyak 27 resep $(6,98 \%)$. Lama pengobatan obat zinc untuk balita yaitu diberikan selama 10 hari dan untuk oralit diberikan sampai diare pada balita berhenti. Beberapa pasien $(6,98 \%)$ diberikan zinc kurang dari 10 hari. Pemberian zinc selama 10 hari terbukti membantu memperbaiki mukosa usus yang rusak dan meningkatkan fungsi kekebalan tubuh secara keseluruhan (Kemenkes, 2011b).

\section{SIMPULAN}

Hasil penelitian menunjukkan bahwa penilaian rasionalitas pengobatan diare pada balita di Puskesmas Bogor Utara Kota Bogor tahun 2016 antara lain berdasarkan tepat indikasi adalah $100 \%$, tepat pemilihan obat $97,93 \%$, tepat dosis $91,73 \%$, tepat cara pemberian $100 \%$, dan tepat lama pengobatan $93,02 \%$.

\section{DAFTAR PUSTAKA}

Departemen Kesehatan RI. 2005. Pedoman Pemberantasan Penyakit Diare. Direktorat Jenderal Pengendalian Penyakit dan Penyehatan Lingkungan. Jakarta.

Dinas Kesehatan Kota Bogor. 2016. Profil Kesehatan Kota Bogor Tahun 2016. Dinas Kesehatan Kota Bogor. Bogor

Hikmawati, H. 2012. Hubungan perilaku ibu dalam penggunaan botol Susu dengan kejadian diare pada balita di ruang Delima RSUD Dr. Harjono Ponorogo. Skripsi. Program Studi D III Keperawatan, Fakultas Ilmu Kesehatan. Universitas Muhammadiyah Ponorogo.

Kementerian Kesehatan RI. 2008. Laporan Riset Kesehatan Dasar (Riskesdas) Tahun 2007. Kementerian Kesehatan RI. Jakarta.
2009.

Pedoman Pemberantasan Penyakit Diare. Direktorat Jenderal Pengendalian Penyakit dan Penyehatan Lingkungan. Jakarta. 2011a. Modul

Penggunaan Obat Rasional. Jakarta: Kementerian Kesehatan.

$2011 b$.

Panduan Sosialisasi Tatalaksana Diare pada Balita. Direktorat Jenderal Pengendalian Penyakit dan Penyehatan Lingkungan. Jakarta.

2014.

Laporan Riset Kesehatan Dasar (Riskesdas) 2013. Kementerian Kesehatan RI. Jakarta.

2015.

Keputusan Menteri Kesehatan Republik Indonesia Nomor Hk.02.02/Menkes/514/2015 Tentang Panduan Praktik Klinis Bagi Dokter di Fasilitas Pelayanan Kesehatan Tingkat Pertama. Kementrian Kesehatan RI. Jakarta.

Made, I.W. 2012. Suplementasi Probiotik Pada Terapi Standar Zinc dan Cairan Rehidrasi Oral Pada Anak Usia 6-36 Bulan Dengan Diare Akut. Tesis Fakultas Kedokteran Universitas Indonesia.

Markum, A.H. 1998. Ilmu Kesehatan Anak; Buku Ajar Jilid 1, Bagian Kesehatan Anak. Universitas Indonesia. Jakarta.

Sukardi, S., S. Yusran, L. Tina. 2016. Faktor-Faktor yang Berhubungan dengan Kejadian Diare pada Balita Umur 6-59 Bulan di Wilayah Kerja Puskesmas Poasia Tahun 2016. Jurnal Ilmiah Mahasiswa Kesehata Masyarakat. 1(3): 1-12.

Wulandari, A. 2012. Penanganan diare di rumah tangga merupakan upaya menekan angka kesakitan diare pada anak balita. Jurnal Health and Sport. 5(2): 1-9. 